\title{
FREKUENSI KEHAMILAN BERHUBUNGAN DENGAN KEJADIAN ABORTUS
}

\author{
Budi Astyandini ${ }^{1}$, Tri Nurhidayati ${ }^{2}$ \\ 1,2 UPP Poltekkes Kemenkes Semarang Kampus Kendal
}

\begin{abstract}
Bleeding is one of the causes of maternal death. Bleeding before the start before the 1st trimester caused by hydatidiform mole, interrupted ectopic pregnancy and abortion. The cause of abortion from maternal faktors is the main faktor causing the abortion. The purpose of this study was to determine the relationship between the frequency of pregnancy and the incidence of abortion in pregnant women. This research is a descriptive correlative study with a population of all pregnant women at Patean Health Center with a total sample of 26 people. The data used were secondary data using an observation sheet in the form of a checklist with univariate and bivariate analysis of the chi-square test at a value of $p<0.05$. The results showed that there was a relationship between abortion and the frequency of pregnancy and the incidence of abortion $p=0.027$. It is recommended that midwives provide more focus on multigravida pregnant women through early detection of pregnancy complications through integrated ancillary services.
\end{abstract}

Keywords : Primigravida; multigravida; multigravida grande; abortion 


\section{PENDAHULUAN}

Abortus merupakan kejadian penghentian kehamilan yang terjadi pada wanita sebelum umur kehamilan 20 minggu dan berat janin kurang dari 500 gram dimana janin belum dapat hidup di luar rahim. Pertumbuhan dan perkembangan janin merupakan peristiwa yang berlangsung secara berkesinambungan dan terus menerus. Setiap waktu pertumbuhan janin dapat mengalami permasalah baik dari faktor maternal, faktor neonatal serta faktor eksternal lainnya. Faktor maternal yang mempengaruhi abortus antara lain usia ibu hamil, jumlah paritas, serta riwayat keguguran sebelumnya, infeksi alat genital, penyakit kronis, kelainan bentuk uterus, Penyakit dalam uterus misalnya mioma, gaya hidup yang tidak sehat, serta stress yang dialami ibu hamil. Faktor neonatal terutama kelainan kromosom. Faktor eksternal yang ada disekitar ibu hamil yang menimbulkan trauma fisik, serta lingkungan tinggal di daerah rawan terhadap radiasi, polusi, pestisida, dan berada dalam medan magnet di atas batas normal. ('MENGENALI ABORTUS DAN FAKTOR YANG BERHUBUNGAN DENGAN KEJADIAN ABORTUS', 2011)

Faktor maternal yang berhubungan dengan abortus berdasarkan hasil penelitian di RS Dr. M. Djamil Padang Tahun 2011-2012 sebanyak 5,83\% kasus abortus, dipengaruhi oleh faktor usia dibawah 20 tahun dan diatas 35 tahun, multi gravida memiliki riwayat abortus, ekonomi kurang dan tingkat Pendidikan menengah kebawah. (Noer, Ermawati and Afdal, 2016)

Faktor penyulit yang membahayakan ibu hamil dan janinnya memerlukan pengawasan, pertolongan, dan pelayanan dengan fasilitas yang memadai. Profesionalisme dari tenaga kesehatan dan kerjasama serta keterpaduan program merupakan solusi yang tepat untuk memberikan pelayanan pada ibu hamil agar angka kematian ibu yang disebabkan perdarahan diawal masa kehamilan. (Manuaba, 2010)

Abortus yang terjadi tanpa adanya intervensi dari luar disebut dengan abortus spontan. Abortus spontan berhubungan dengan faktor maternal dan ekternal. Hasil peneltian di RSUD Kabupaten Temanggung tahun 2015 - 2016 di dapatkan terdapat hubungan antara abortus spontan dengan riwayat graviditas $(p=0,025)$, faktor yang banyak mempengaruhi adalah jarak kehamilan, umur ibu saat hamil, riwayat kejadian abortus sebelumnya, adanya riwayat paparan asap rokok serta pengaruh dari usia saat menikah. (Purwaningrum et al., 2017)

Berdasarkan survey awal yang dilaksanakan di Puskesmas Patean didapatkan $11 \%$ ibu hamil mengalami abortus terjadi pada usia reproduksi sehat antara 20 - 35 tahun. Berdasarkan latar belakang diatas penting dilakukan penelitian tentang status gravida ibu hamil 
berhubungan dengan kejadian abortus pada ibu hamil

\section{METODOLOGI PENELITIAN}

Penelitian ini merupakan penelitian deskriptif analistik dengan mengunakan total populasi sebagai sampel sejumlah 26 ibu hamil yang tinggal di wilayah Puskesmas Patean serta mengalami abortus pada bulan Agutus sampai September 2021. Data yang digunakan berupa data sekunder menggunakan data dari laporan bulanan bidan dan buku KIA ibu hamil yang mengalami abortus. Alat pengumpul data adalah lembar observasi berupa checklist yang langsung dilakukan oleh peneliti. Data yang terkumpul kemudian dianalisis berdasarkan frekuensi. Hubungan antara gravida dan kejadian abortus di analisis dengan uji statistik Chi-Square dengan $p$ value $0,000 \leq \alpha(0,05)$

Jenis Penelitian ini menggunakan studi quasy eksperimental dengan one group pre test post test design menggunakan pendekatan cross sectional. Populasi penelitan ini adalah semua kader IVA di Desa Bejiruyung Kecamatan Sempor Kabupaten Kebumen sejumlah 35 orang. Teknik pengambilan sampel pada penelitian ini adalah total sampling. Kegiatan penelitian terdiri 3 tahap, yaitu pre test, kegiatan penelitian dan post test. Pada tahap pre-test peneliti bersama enumerator melakukan penilaian menggunakan check list sebelum diberikan intervensi refreshing kader IVA selama 4 jam. Kegiatan penelitian dilakukan pada masa pandemi Covid-19 sehingga sampel dibagi 2 periode intervensi. Periode I dilakukan pada pagi hari (pukul 08.00 - 12.00 WIB) sejumlah 20 orang kader dan periode 2 dilakukan pada siang hari (pukul $13.00-17.00$ WIB) sejumlah 15 orang kader. Pertemuan dilaksanakan sesuai protokol kesehatan dengan menjaga jarak, menggunakan masker dan menyiapkan hand sanitizer. Pengambilan post test ketrampilan kader dilaksanakan 2 (dua) minggu setelah pemberian intervensi. Analisa bivariat penelitian ini menggunakan uji statistik Wilcoxon dengan taraf signifikan 0,05.

\section{HASIL PENELITIAN DAN BAHASAN}

Tabel 1. Distribusi frekuensi berdasarkan kejadian abortus

\begin{tabular}{|c|c|c|c|}
\hline & Frekuensi & $\%$ & Total \\
\hline Tidak abortus & 21 & 81 & 81 \\
\hline Abortus & 5 & 19 & 19 \\
\hline Total & 26 & 100 & 100 \\
\hline \multicolumn{4}{|c|}{$\begin{array}{l}\text { Hasil penelitian tabel } \\
\text { menunjukkan sebagian besar ibu hami } \\
\text { tidak mengalami abortus sebanyak } 81 \% \\
\text { dan } 19 \% \text { ibu hamil mengalami abortus. } \\
\text { Tabel } 2 \text {. Distribusi frekuensi berdasarkan } \\
\text { gavida pada ibu hamil }\end{array}$} \\
\hline & Frekuensi & $\%$ & Total \\
\hline Bukan Multi & 3 & 12 & 12 \\
\hline Multigravida & 23 & 88 & 88 \\
\hline Total & 26 & 100 & 100 \\
\hline
\end{tabular}


Hasil penelitian tabel 2 menunjukan sebagian ibu hamil adalah multigravida sebanyak $88 \%$, sedangkan yang bukan multigravida sebagian kecil mengalami abortus sebanyak $12 \%$.

Hasil penelitian hubungan antara gravida dengan abortus didapatkan hasil pada kelompok bukan multigravida sebagian besar mengalami abortus sebanyak 75\% sedangkan pada multigravida sebagian kecil yaitu sebanyak 12,5\% mengalami abortus dan dapat disimpulkan ada hubungan antara gravida dengan abortus dengan $p<0,027$.

\section{Frekuensi kehamilan}

Frekuensi kehamilan adalah jumlah keamilan yang pernah dialami seorang wanita (Gravida). Berdasarkan hasil penelitian di RSUD Kabupaten Temanggung tahun 2015 - 2016 didapatkan terdapat faktor resiko terjadinya abortus spontan antara lain berhubungan dengan riwayat graviditas $(p=0,025)$ (Purwaningrum et al., 2017)

Pada kehamilan primigravida seorang ibu hamil secara fisik tubuhnya mengalami adaptasi pertama kalinya dengan perubahan hormonal di dalam tubuhnya sebagai kompensasi adanya janin di dalam uterus yang berkembang dan memerlukan tempat dan nutrisi bagi pertumbuhan janin reaksi yang berlebihan menimbulkan kontraksi dan berakhir dengan abortus. Beberapa faktor yang menyebabkan abortus pada primigravida dapat disebabkan karena frekuensi seksual, usia saat pertama kali hamil, pengetahuan dan sosial ekonomi.

Penelitian di RSUD Dr. Chasan Boesoirie Ternate didapatkan hasil variabel yang berisiko terhadap kejadian abortus yaitu: jumlah paritas OR = 2,98 $(95 \% \mathrm{Cl}: 1,502-$ 5,933; $p=0,003$ ). (Hubaya, Arifin and Burhanuddin, 2015)

Ibu hamil primigravida di Puskesmas Patean sebagian besar adalah mereka yang menikah dibawah usia 20 tahun dengan tingkat Pendidikan dan sosial ekonomi yang rendah sehingga memicu terjadinya abortus karena kurang pengetahuan tentang kehamilan dan perawatan di awal kehamilan.

\section{Kehamilan Grande multigravida}

Grande Multigravida merupakan kehamilan yang dialami seorang wanita lebih dari 5 kali. Kehamilan multigravida merupakan kondisi yang sangat rawan terhadap terjadinya abortus. Faktor yang mempengaruhi antara lain karena usia ibu lebih dari 35 tahun yang masuk kategori usia tidak sehat. Pada usia yang relative tua dapat mempengaruhi kualitas sel telur yang dihasilkan serta penyakit degeneratif yang dialami ibu hamil dapat memicu terjadinya abortus. Pada multigravida walaupun seorang wanita telah memiliki pengalaman adaptasi kehamilan sebelumnya, namun faktor lain yang mempengaruhi adalah jarak dari kehamilan, kondisi status gizi ibu selama kehamilan.

Kejadian Abortus yang dialami ibu hamil dapat mengakibatkan kondisi buruk 
pada ibu antara lain adalah perdarahan, perforasi uterus terutama pada uterus dalam posisi hiperretofleksi, syok hemoragik, infeksi dan juga kematian pada ibu. Untuk mengurangi efek yang ditimbulkan dari terjadinya abortus pada ibu, maka perlu mengetahui faktor-faktor yang mempengaruhi abortus sehingga sedini mungkin dapat dicegah atau diberikan asuhan yang tepat.penelitian sesuai dengan penelitian di RSUD Goeteng Taruna dibrata Purbalingga. Didapatkan hasil Ada hubungan yang signifikan antara usia ibu hamil $(p<0.01$; $r=0.297)$, status gravida $(p<0.01 ; r=-$ $0.272)$ usia kehamilan ( $p<0.05 ; r=-0.224)$. paritas dengan kejadian abortus $(p<0.05$; $r=-0.252$ ). Hasil penelitian juga menyebutkan bahwa Umur kehamilan merupakan faktor yang paling menentukan dalam terjadinya abortus pada ibu hamil $(t=-13.093 ; p<0.01$; partial correlation $=-0.751)($ Yanti, 2018)

\section{Determinan kejadian abortus}

Trimester I adalah masa dimana 3 bulan pertama kehamilan yakni 0 sampai 12 minggu awal kehamilan. Pada masa ini tubuh ibu akan banyak mengalami perubahan seiring berkembangnya janin. Pada ibu-ibu hamil pada fase trimester I terkadang ditemukan beberapa gangguan kehamilan yaitu, Abortus, Anemia Kehamilan, Hiperemesis Gravidarum tingkat I, Hiperemesis Gravidarum tingkat II, Kehamilan Ektopik, dan Mola hidatidosa. Untuk membantu pasien dalam mengenali gangguan kehamilan pada trimester I ini maka Hasil penelitian tentang sistem yang menerapkan konsep jaringan syaraf tiruan dengan metode LVQ 2 (Learning Vector Quantization) dalam mengenali gangguan kehamilan trimester I didaptkan : gejala yang menjadi gangguan kehamilan trimester I terdiri dari Ada 41 gejala penyakit, dan 6 penyakit sebagai data masukan. Sistem akan mengklasifikasikan penyakit dengan proses pembelajaran dan pengujian ke dalam 6 jenis penyakit, berdasarkan pengujian metode LVQ2 cukup baik di terapkan dalam pengenalan pola gejala gangguan kehamilan, data latih 90 dan data uji 18 didapat akurasi terbaik 100\% dan rata-rata akurasi $97.68 \%$. (Budianita, 2018)

\section{Abortus spontan}

Abortus spontan merupakan kasus yang paling banyak terjadi. Abortus yang merupakan pengeluaran hasil konsepsi terjadi secara spontan tanpa adanya isuatu tindakan. Komplikasi dari Abortus spontan adalah terjadinya perdarahan dapat disebabkan karena adanya sebagian placental site masih terbuka sehingga perdarahan terus berlangsung. Ibu hamil dengan kasus ini apat mengalami anemia atau syok hemoragik sebelum sisa jaringan konsepsi dikeluarkan. Hasil penelitian di RSUD dr. Soeselo Kabupaten Tegal. Didapatkan hasil abortus 50\% , 75\% dengan umur berisiko (usia <20tahun dan >35 tahun) dan $25 \%$ (10 ibu) dengan usia reproduksi sehat (usia 20-35 tahun 
terdapat hubungan antara umur ibu dengan kejadian abortus ( $p$ value $=0.03$ ) Akibat dari Kekurangan zat besi pada wanita hamil dapat menyebabkan gangguan ataupun hambatan pada pertumbuhan janin, baik sel tubuh maupun sel otak. Anemia gizi dapat mengakibatkan kematian janin didalam kandungan, abortus, cacat bawaan, BBLR, anemia pada bayi yang dilahirkan. Perdarahan yang banyak menyebabkan kematian ibu.

Penelitian tentang hubungan antara tingkat anemia dengan kejadian abortus pada ibu hamil di wilayah kerja Puskesmas Ngadi kecamatan Mojo relative tua dapat mempengaruhi kualitas sel telur yang dihasilkan serta penyakit degenartif yang dialami ibu hamil dapat memicu terjadinya abortus.

Pada multigravida walaupun seorang wanita telah memiliki pengalaman adaptasi kehamilan sebelumnya, namun faktor lain yang mempengaruhi adalah jarak dari kehamilan, kondisi status gizi ibu selama kehamilan.

Kejadian Abortus yang dialami ibu hamil dapat mengakibatkan kondisi buruk pada ibu antara lain adalah perdarahan, perforasi uterus terutama pada uterus dalam posisi hiperretofleksi, syok hemoragik, infeksi dan juga kematian pada ibu. Untuk mengurangi efek yang ditimbulkan dari terjadinya abortus pada ibu, maka perlu mengetahui faktor-faktor yang mempengaruhi abortus sehingga sedini mungkin dapat dicegah atau diberikan asuhan yang tepat. Penelitian sesuai dengan penelitian di RSUD Goeteng Taruna dibrata Purbalingga. Didapakan hasil Ada hubungan yang signifikan antara usia ibu hamil $(\mathrm{p}<0.01$; $r=0.297)$, status gravida $\quad(p<0.01 ; r=-$ $0.272)$ uisa kehamilan $(p<0.05 ; r=-$ 0.224). paritas dengan kejadian abortus $(p<0.05 ; r=-0.252)$. hasil penelitian juga menyebutkan bahwa Umur kehamilan merupakan faktor yang paling menentukan dalam terjadinya abortus pada ibu hamil $(t=-13.093 ; p<0.01$; partial correlation $=-0.751)($ Yanti, 2018)

\section{Determinan kejadian abortus}

Trimester I adalah masa dimana 3 bulan pertama kehamilan yakni 0 sampai 12 minggu awal kehamilan. Pada masa ini tubuh ibu akan banyak mengalami perubahan seiring berkembangnya janin. Pada ibu-ibu hamil pada fase trimester I terkadang ditemukan beberapa gangguan kehamilan yaitu, Abortus, Anemia Kehamilan, Hiperemesis Gravidarum tingkat I, Hiperemesis Gravidarum tingkat II, Kehamilan Ektopik, dan Mola hidatidosa. Untuk membantu pasien dalam mengenali gangguan kehamilan pada trimester I ini maka Hasil penelitian tentang sistem yang menerapkan konsep jaringan syaraf tiruan dengan metode LVQ 2 (Learning Vector Quantization) dalam mengenali gangguan kehamilan trimester I didapatkan gejala yang menjadi gangguan kehamilan trimester I terdiri dari Ada 41 gejala penyakit, dan 6 penyakit sebagai 
data masukan. Sistem akan mengklasifikasikan penyakit dengan proses pembelajaran dan pengujian ke dalam 6 jenis penyakit, berdasarkan pengujian metode LVQ2 cukup baik di terapkan dalam pengenalan pola gejala gangguan kehamilan, data latih 90 dan data uji 18 didapat akurasi terbaik 100\% dan rata-rata akurasi $97.68 \%$ (Budianita, 2018)

\section{Abortus spontan}

Abortus spontan merupakan kasus yang paling banyak terjadi. Abortus yang merupakan pengeluaran hasil konsepsi terjadi secara spontan tanpa adanya isuatu tindakan. Komplikasi dari Abortus spontan adalah terjadinya perdarahan dapat disebabkan karena adanya sebagian placental site masih terbuka sehingga perdarahan terus berlangsung. Ibu hamil dengan kasus ini apat mengalami anemia atau syok hemoragik sebelum sisa jaringan konsepsi dikeluarkan.. hasil penelitian di RSUD dr. Soeselo Kabupaten Tegal. Didaptkan hasil abortus $50 \%$, $75 \%$ dengan umur berisiko (usia $<20$ tahun dan $>35$ tahun) dan $25 \%$ (10 ibu) dengan usia reproduksi sehat (usia 20-35 tahun terdapat hubungan antara umur ibu dengan kejadian abortus ( $p$ value $=0.03$ ) Akibat dari Kekurangan zat besi pada wanita hamil dapat menyebabkan gangguan ataupun hambatan pada pertumbuhan janin, baik sel tubuh maupun sel otak. Anemia gizi dapat mengakibatkan kematian janin didalam kandungan, abortus, cacat bawaan, BBLR, anemia pada bayi yang dilahirkan. Perdarahan yang banyak menyebabkan kematian ibu.

\section{KESIMPULAN}

Terdapat hubungan antara Frekuensi kehamilan dengan abortus. Sebagain kecil multigravida mengalami abortus. Kejadian abortus adalah yang pertama kali $83,3 \%$ disarankan pelayanan kebidanan pada ibu hamil sebelum usia kehamilan 20 minggu diprioritaskan untuk deteksi dini faktor penyebab abortus dan penyakit penyerta pada wanita hamil serta memberikan perhatian pada ibu hamil multigravida dengan perbaikan gizi dan pemberian pelayanan ANC yang terintegrasi.

\section{DAFTAR PUSTAKA}

1. Budianita, E. B. (2018) 'Penerapan Metode Learning Vector Quantization2 (LVQ 2) Untuk Menentukan Gangguan Kehamilan Trimester I', Jurnal Sains dan Teknologi Industri. doi: 10.24014/sitekin.v15i2.4861.

2. Heryanti, H. (2018) 'Hubungan Umur dan Paritas Ibu Hamil Dengan Kejadian Abortus Inkomplit di Rumah Sakit Muhammadiyah Palembang Tahun 2017', JPP (Jurnal Kesehatan Poltekkes Palembang). doi: 10.36086/jpp.v13i1.83.

3. Hubaya, S., Arifin, M. and Burhanuddin, B. (2015) 'Faktor Risiko Kejadian Abortus Di Rsud Dr. Chasan 
Boesoirie Ternate Provinsi Maluku Utara', Jurnal Kesehatan Poltekkes Ternate.

4. Jayani, I. (2017) 'Tingkat Anemia Berhubungan Dengan Kejadian Abortus Pada Ibu Hamil', Jurnal IImiah IImu Kesehatan. doi: 10.33366/CR.V5I1.390.

5. Manuaba, I. (2010) 'Memahami Kesehatan Reproduksi Wanita', Jakarta: Arcan.

6. 'MENGENALI ABORTUS DAN FAKTOR YANG BERHUBUNGAN DENGAN KEJADIAN ABORTUS' (2011) Idea Nursing Journal.

7. Noer, R. I., Ermawati and Afdal (2016) 'Karakteristik Ibu pada Penderita Abortus dan Tidak Abortus', Jurnal Kesehatan Andalas.

8. Prihandini, S. R., Pujiastuti, W. and Hastuti, T. P. (2016) 'USIA REPRODUKSI TIDAK SEHAT DAN JARAK KEHAMILAN YANG TERLALU DEKAT MENINGKATKAN KEJADIAN ABORTUS DI RUMAH SAKIT TENTARA DOKTER SOEDJONO MAGELANG', JURNAL KEBIDANAN.

9. Purwaningrum, E. D. et al. (2017) 'Faktor Risiko Kejadian Abortus Spontan', Public Health Research and Development.

10.Risma, Malahika, J. M., Karamoy, H. and Pusung (2017) 'Faktor Risiko Maternal Kejadian Abortus', Jurnal Riset kuntansi Going Concern.

11.Yanti, L. (2018) 'Faktor determinan kejadian abortus pada ibu hamil: case control study', MEDISAINS. doi: 10.30595/medisains.v16i2.3002. 